\title{
Membangun Sense Of Belonging Masyarakat Melalui Pemanenan Air Hujan Dalam Telaah Ecology Citizenship
}

\author{
Dewi Gunawati \\ Universitas Sebelas Maret Surakarta \\ Email: dewigunawatiuns@yahoo.co.id
}

\begin{abstract}
ABSTRAK
Tulisan ini beranjak dari pencermatan destruksi lingkungan yang berbentuk kekeringan, banjir, penurunan muka air tanah yang terus mengalami peningkatan, kualitas penurunan air tanah, kebutuhan air yang meningkat, kebakaran hutan yang terus berlangsung. Air merupakan salah satu sumber daya alam yang sangat dibutuhkan seluruh makluk hidup. Krisis air memaksa manusia untuk meredefinisi ulang implementasi konsep keadilan antar generasi dalam pemanfaatan sumber daya alam. Krisis air memaksa munculnya sebuah gerakan masyarakat secara " pentahelijk" untuk menemukan alternatif sumber air bagi kebutuhan hidup. Gerakan itu disebut dengan Gerakan Memanen Hujan yang sudah eksis dan berkembang diberbagai daerah di Indonesia. Tujuan tulisan : Membangun sense of belonging masyarakat melalui pemanenan air hujan dalam telaah ecologi citizenship. Metode pengumpulan data yang digunakan adalah penelusuran data kepustakaan, yang didukung dengan dokumentasi, wawancara dan observasi. Sumber data adalah Pendiri dan pengurus Komunitas Pemanenan Air Hujan "Banyu Bening" di Sleman. Pembahasan : Gerakan memanen air hujan merupakan kegiatan untuk menampung air hujan, memanfaatakan secara maksimal,meresapkan kedalam tanah dan mengalirkannya kembali. Kegiatan ini merupakan salah satu alternatif dalam mitigasi lingkungan, dalam telaah Ecological Citizenship diistilahkan dengan "memikirkan kewarganegaraan dengan cara-cara agak baru" yang dikaitkan dengan hak dan kewajiban warga negara dalam mencapai lingkungan yang bersih dan sehat.
\end{abstract}

Kata kunci: rekonstruksi, air hujan, ecologi.

\section{PENDAHULUAN}

Tulisan ini beranjak dari pencermatan penulis terhadap kondisi lingkungan yang mengalami penurunan kualitas dan kuantitas. Salah satu bentuk destruksi lingkungan adalah banjir dan kekeringan. Kekeringan merupakan bencana yang sering terjadi di beberapa wilayah di Indonesia, Merujuk (BMKG), Beberapa wilayah Indonesia mendapat curahan hujan berkisar intesitas 150-200 mm sampai 400-500 mm. Kondisi ini berdampak pada bencana banjir yang terjadi dibeberapa daerah. Bencana banjir merupakan salah satu bentuk krisis sumber daya alam yang melingkupi: berbagai masalah: Pemanfaatan air yang belum merata bagi seluruh warga masyarakat, Pengelolaan sumber daya air yang masih belum mencerminkan asas keadilan dalam satu generasi terlihat pada peningkatan kebutuhan air namun 
sumber daya alam kurang mencukupi dan mungkin langka(scarcity), Penggunaan drainase konvensional yang menyalurkan air ke hilir, intensitas kekeringan yang meningkat , penurunan muka air tanah terus meningkat ,penurunan kualitas air tanah menurun ,Masalah pengelolaan sumber daya air yang berpotensi pada masalah sanitasi kesehatan dalam wujud munculnya berbagai penyakit yang diakibatkan oleh kualitas air yang tidak memenuhi standar air minum.

Anugerah Allah yang maha kuasa yang harus disyukuri adalah sumber daya air. Kelangsungan hidup makluk hidup menyandarkan pada eksistensi sumber daya air. Air adalah simbol kehidupan selain udara. Air yang turun dari langit adalah sebuah keberkahan Ilahi yang tersurat dalam kalam Ilahi Rabbi:

QS Az Zumar ayat 21:

Allah SWT. berfirman لَّ نَ

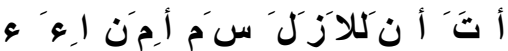

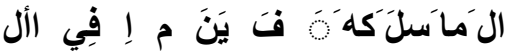

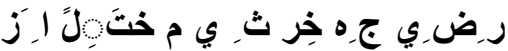

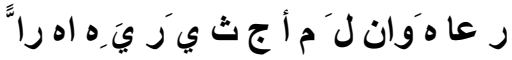

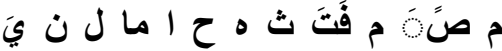

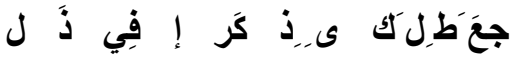

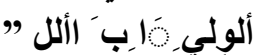

Apakah kamu tidak memperhatikan bahwa sesungguhnya Allah menurunkan air dari langit, maka diatur-Nya menjadi sumber-sumber di bumi kemudian ditumbuhkannya-
Nya dengan air itu tanamantanaman yang bermacammacam warnanya, lalu ia menjadi kering lalu Kami melihatnya kekuningkuningan, kemudian dijadikan-Nya hancur berderai-derai. Sesungguhnya pada yang demikian itu benarbenar terdapat pelajaran bagi orang-orang yang berakal". (QS.Az-Zumar,39:21).

Allah SWT. berfirman

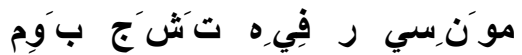

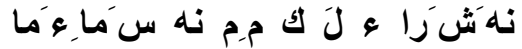

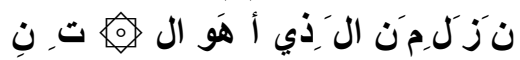

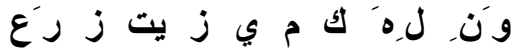

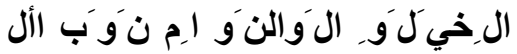

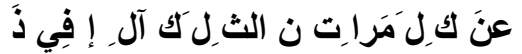

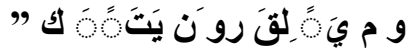

Dialah yang telah menurunkan air hujan dari langit untuk kamu, sebagiannya menjadi minuman dan sebagiannya (menyuburkan) tumbuhtumbuhan, yang pada (tempat tumbuhnya) kamu menggembalakan ternakmu. Dia menumbuhkan bagi kamu dengan air hujan itu tanamantanaman; zaitun, kurma, anggur dan segala macam buah-buahan. Sesungguhnya pada yang demikian itu benar-benar ada tanda (kekuasaan Allah) bagi kaum yang memikirkan.'“ (An-Nahl, 10-11) 
Ibnu Katsir menjelaskan, "Mikail ditugaskan untuk mengurus hujan dan tumbuh-tumbuhan yang darinya berbagai rizki diciptakan di alam ini. Mikail memiliki beberapa pembantu. Mereka melaksanakan apa yang diperintahkan kepada mereka melalui Mikail berdasarkan perintah dari Allah. Mereka mengatur angin dan awan, sebagaimana yang dikehendaki oleh Rabb yang Maha Mulia. Sebagaimana pula telah kami riwayatkan bahwa tidak ada satu tetes pun air yang turun dari langit melainkan Mikail bersama malaikat lainnya menurunkannya di tempat tertentu di muka bumi ini (Al Bidayah wan Nihayah, 1/50.)

Firman Allah diatas menjelaskan bahwa Air merupakan salah satu sumber daya alam yang sangat dibutuhkan seluruh makluk hidup. Krisis air memaksa manusia untuk meredefinisi ulang implementasi konsep keadilan antar generasi dalam pemanfaatan sumber daya alam. Krisis air memaksa munculnya sebuah gerakan masyarakat secara " pentahelijk" untuk menemukan alternatif sumber air bagi kebutuhan hidup. (Maryono, 2020) Gerakan itu disebut dengan Gerakan Memanen Hujan yang sudah eksis dan berkembang diberbagai daerah di Indonesia.

\section{METODE PENELITIAN}

Metode Penelusuran data kepustakaan, yang didukung dengan dokumentasi yang ada di Komunitas atau gerakan pemanenan air hujan. Wawancara Penginisiasi pemanfaatan air hujan, wawancara dengan Pendiri dan pengurus Komunitas Banyu Bening, salah satu Komunitas pemanenan air hujan yang berlokasi di Sleman, Yogyakarta.

\section{PEMBAHASAN}

\section{Telaah Ecology Citizenship}

Rilley Dunlap, seorang pakar lingkungan hidup dan sosiolog dari Universitas Oklahoma, menjelaskan bahwa destruksi lingkungan terjadi karena perilaku manusia yang memiliki sesat pikir terhadap sumber daya manusia yang tidak terbatas. Pertumbuhan produksi dan konsumsi dengan indikator-indikator ekonomi menjadikan legitimasi dominasi manusia terhadap alam (Buttel, 2010) Dalam dalil ini, kemajuan manusia berawal dari kepercayaan bahwa teknologi merupakan solusi dari masalah sosial atau fisik yang dapat muncul dalam masyarakat (Kilbourne, 2007) 2008). Adapun penggunaan teknologi merupakan bagian dari pandangan Paradigma Barat (Dominant Western Worldview$D W W$ ) atau disebut Dominant Social Paradigm (DSP). (https://www.mongabay.co.id/2018/0 4/22/menyelamatkan-bumi-yangsatu-lewat-perilaku-pro-lingkungan/ 
New Ecological Paradigm (Kent, 2008) merupakan paradigm baru yang menolak keberadaan alam semata sebagai bahan eksploitasi kebutuhan manusia. Rekonstruksi paradigma baru dan nilai etik, yang mengatur hubungan manusia dengan alam. Merupakan hal yang urgensif. Pemikiran Dunlap bertolak dari dalil yang menyebutkan sebagai berikut (Riley Dunlap\&Catton, 1979) (1) manusia hanya satu spesies yang terdiri dari banyak spesies yang memiliki ketergantungan dalam komunitas biotik yang membentuk kehidupan sosial; (2) Keterkaitan yang rumit menyebabkan dampak dan memberi umpan balik pada jaringan alam yang memunculkan konsekuensi yang tidak diinginkan yang berbeda dengan aksi manusia yang disengaja; (3) Potensi keterbatasan fisik dan biologis menghambat pertumbuhan ekonomi, kemajuan sosial dan fenomena kemasyarakatan lainnya.

Kewarganegaraan ekologi merupakan gagasan baru yang diupayakan untuk membentuk manusia seutuhnya dalam keterlibatan menjaga pelestarian lingkungan hidup. (Curtin, 2002) Gagasan ini muncul seiring kondisi dunia yang sedang dlm keadaan krisis ekologis yang berkepanjangan. Istilah ini muncul dari LSM di Kanada,Muncul karena sebagian warga dunia tidak memiliki sejarah yang baik dalam mengelola lingkungan.
Ekologi kewarganegaraan mencakup lima komponen yang merupakan bagian sistem kewarganegaraan yang meliputi: a). Kewarganegaraan ekologis (Ecology literacy-( memahami sistem ekologis utama dengan ,pemikiran ekologis,memahami sifat ilmu ekologi dan hubungannya dengan masyarakat), b). Civic Literacy(memahami sistem sosial,ekonomi, budaya dan masyarakat,, c).Value Awareness-( Kesadaran akan nilainilai pribadi berkenaan dengan lingkungan)(pengetahuan untuk menghubungkan nilai dengan pengetahuan dan kebijakan praktis untuk membuat keputusan dan tindakan),d).Self

Eficiency(kemampuan untuk belajar dan bertindak berkenaan dengan nilai dan kepentingan pribadi dan lingkungan),e).Practical Wisdom-( Memiliki kebijaksanaan praktis dan ketrampilan untuk pengambilan keputusan dan bertindak berkenaan dengan lingkungan.(Berkowit, et all,2005)

Interaksi antara sistem sosial dan lingkungan perlu dibangun dalam perwujudan sebuah relasi baru. Sebuah organisasi sosial yang membentuk sistem sosial (nilai, ideologi, kepribadian, pola eksploitasi sumber daya, organisasi sosial) pun harus terbentuk di atas nilai kesadaran dan norma yang bersama-sama faktor pengetahuan dan niat mendorong dan membentuk perilaku ekologi (Fernandez Manzanal, 2007) 
Menurut Strong (1995) kunci untuk memperbaiki bumi terletak pada penghorma-tan terhadap hukum alam yang dipahami oleh masyarakat asli tradisional. Masyarakat ini berbicara dengan kumpulan instruksi yang asli yang diberikan kepada mereka oleh Sang Pencipta. Mereka mengetahuinya dan meng-hidupi hukum ini, yang menuntun relasi manusia dengan empat elemen pemberi ke-hidupan, yakni, tanah, air, udara, dan api (energi); serta mengajarkan penghormatan kepada kesatuan dan kesinambungan dari seluruh kehidupan. "Tidak ada jalan lain un-tuk perdamaian kecuali semua orang harus meninggalkan gerbang istana persepsi yang relatif, turun ke padang rumput, dan kembali ke jantung alam yang non-aktif. Marilah kita katakana bahwa kunci perdamaian terletak dekat di bumi”.

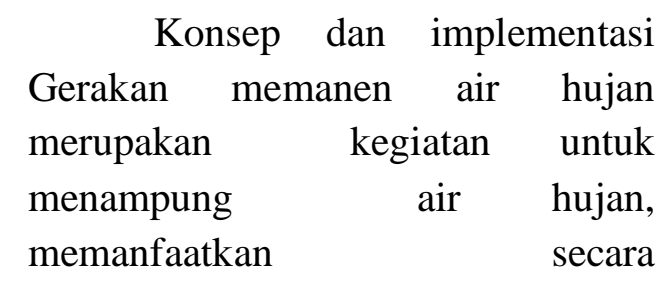
maksimal,meresapkan kedalam tanah dan mengalirkannya kembali. Kegiatan ini merupakan salah satu alternatif dalam mitigasi lingkungan, dalam telaah Ecological Citizenship diistilahkan dengan "memikirkan kewarganegaraan dengan cara-cara agak baru" yang dikaitkan dengan hak dan kewajiban warga negara dalam mencapai lingkungan yang bersih dan sehat. Gerakan memanen air hujan berbasis masyarakat secara "pentahelik" untuk menampung air hujan, memanfaatkan semaksimal mungkin, meresapkan ke dalam tanah, mengalirkan kelebihannya dan memelihara semua infrastruktur fisik dan sosial terkait air hujan. (Maryono, 2020)

Mengapa gerakan memanen air hujan muncul dan tumbuh? Kondisi dan Anggapan serta Perilaku Masyarakat, Air hujan dilupakan masyarakat, Air hujan dibuang- buang mendatangkan banjir , Air hujan dianggap tidak memenuhi kualitas ,Proyek Drainase mebuang air hujan, Kekeringan meluas dan meningkat Perubahan Iklim.(Agus Maryono,2020)

Gerakan memanen air hujan di Indonesia di bedayakan oleh sebuah komunitas yang disebut dengan Komunitas pemanenan air hujan. Berikut komunitas pemanenan air hujan: Komunitas sedekah air hujan Sleman, Komunitas Banyu Bening Sleman ,Komunitas Kandang Hujan Klaten ,Komunitas Tahta air langit Jakarta ,Komunitas air hujan Jombang ,Komunitas air hujan Buton ,Komunitas air hujan Padang ,Komunitas air makmur Sukoharjo ,Komunitas air hujan Banjarmasin, dan seterusnya. Pengejawantahan konsep kewarganegaraan menurut kalidjernih berdampak pada munculnya gerakan-gerakan lingkungan. (FK, 2011) Gerakan lingkungan dibagi menjadi tiga gerakan kewarganegaraan ekologis (Aditjondro, 2003) yaitu: (a) Sifat 
gerakan adalah volunter /sukarela dan terorganisir: WALHI di Indonesia, (b) Gerakan lingkungan publik yang merupakan bentuk gerakan berbasis masyarakat, aktivitas yang dilakukan konsen terhadap keutuhan fungsi lingkungan (c) Gerakan lingkungan yang berbasis pemerintah atau lembaga-lembaga yang dibentuk oleh pemerintah mengenai upaya penanganan masalah lingkungan hidup seperti Dinas Lingkungan Hidup di Indonesia. Gerakan lingkungan mempunyai konsistensi dalam menangani isu-isu permasalahan lingkungan yang ada mereka dijuluki sebagai penyelemat lingkungan.

Definisi kewarganegaraan ekologis dari Kennedy (2011) adalah memasukkan dimensi budaya informasi yang berbasis lingkungan. (Jagers, 2014) menafsirkannya dengan keadilan sosial, menantang perbedaan publik-swasta dan tanggung jawab. (D, 2009)mendefinisikan sebagai kegiatan yang berusaha untuk memiliki suara keadilan bagi masyarakat miskin pedesaan, masyarakat adat dan kelompokkelompok terpinggirkan lainnya. (D, 2009)

Anantharaman

(Anantharaman, 2014)menyoroti keterlibatan sukarela oleh individuindividu melalui mata pencaharian dalam menghasilkan sistem perilaku peduli lingkungan, sedangkan Smith
\& Pangsapa (2008) melihat pada aspek politik kewajiban pada ikatan antar aktor seperti organisasi sipil, pemerintah, dan badan antar pemerintah. Pencegahan masalahmasalah lingkungan dengan membentuk kewarganegaraan ekologis dapat dilakukan melalui LSM dan komunitas lainnya yang kompromi dan adil untuk mencapai keseimbangan pengelolaan sumber daya alam (Keulartz, 2018). (Smith\&Pangsapa, 2008). Setiap warga negara berkewajiban dan bertanggung jawab untuk menjaga lingkungan hidup yang baik dan sehat (Asshiddiqie, 2009). Partisipasi warga negara dalam mencegah pencemaran, kerusakan, dan melestarikan lingkungan hidup dapat dilakukan dengan kerja sama semua lapisan masyarakat. Upaya pembentukan karakter peduli lingkungan dilaksanakan melalui: pendidikan lingkungan, penegakan hukum yang jelas, dan kampanye media sosial.Konsep kewarganegaraan ekologis ditentukan dalam upaya untuk memperluas hakhak lingkungan berlandaskan hukum, budaya kearifan lokal, dan politik. (Assshiddiqie, 2009)

\section{Membangun Sense of Belonging Masyarakat dalam Pemanfaatan air hujan}

Menumbuhkan sense of belonging, Pemaknaan Sense of belonging sebagai “ rasa memiliki”Ketika 
seseorang merasa memiliki, merasa diterima, dan diakui sebagai bagian dari suatu kelompok. Menurut Abraham Maslow dalam teorinya Maslow's hierarchy of needs, Sense of belonging ini posisinya setelah kebutuhan fisiologis dan rasa aman.

Sense of belonging atau rasa memiliki merupakan perasaan yang dimiliki oleh setiap orang terhadap sesuatu yang dia sukai sehingga senantiasa melakukan segala hal dengan ikhlas demi menjaga eksistensi sesuatu yang dia sukai tersebut. Sense of belonging dapat diartikan banyak hal. Sense of belonging yang ada dalam tiap individu tidak dapat dibentuk secara instan. Dibutuhkan tindakan yang berulang-ulang sampai seseorang tidak perlu berpikir dua kali untuk melakukan suatu hal.

DR.RobiyantoTan:"Rasa memiliki (sense of belonging) merupakan ekspresi jiwa yang penting dalam kehidupan seseorang. Rasa memiliki juga akan memiliki dampak yang nyata terlihat secara signifikan di dalam perilaku seseorang. Seseorang yang memiliki rasa memiliki akan bertindak peduli, terikat, memiliki empati, termotivasi bahkan mampu memberdayakan dirinya sendiri meskipun tidak ada stimulan.“ Merujuk James Gilmore: a sense of belonging is the feeling of being connected and accepted within one's family and community. It is important in healthy human development and combating behavior problems and depression.

Menumbuhkan sense of belonging dalam budaya jawa dikenal dengan rasa memiliki dikenal di Masyarakat Jawa sebagai handarbeni, sedangkan psikologi mengenalnya sebagai sense of belonging. Handarbeni merupakan bagian dari prinsip kepemimpinan yang diperkenalkan oleh Mangkunegara IV di dalam Serat Wedhatama, yang kemudian dikenal sebagai Tri Dharma. Ketiga dharma yang dimaksud ini menurut (Saddono, 2013) memiliki makna sebagai: (1) rumangsa melu handarbeni (dimaknai sebagai having sense of belongingatau rasa memiliki), (2) Wajib melu hanggondheli (hangrungkepi) (dimaknai sebagai having sense of defence atau mempertahankan), (3) Mulat sarira hangrasa wani (dimaknai sebagai after self-awareness have a braveness to actatau mawas diri). Rasa memiliki diwujudkan dalam perilaku memperhatikan kebersihan lingkungan, merawat sarana dan prasarana aset lembaga.

Handarbeni tidak sebatas rasa memiliki, namun ada perasaan terlibat di dalam organisasi sehingga muncul rasa tanggung jawab atas nasib dan keberlanjutan organisasi.:

1) Usefulness-(Kemanfaatan)

Memiliki pengetahuan dan pemahaman yang baik tentang lingkungan dan pembangunan berkelanjutan,memiliki pengetahuan 
tentang pemanen air hujan, konsep, kegunaan, implementasi dan mekanisme,merasakan kemanfaatan dari kegiatan pemanenan air hujan,

2) Doktrin-Ajaran yang bersifat mendorong,

Dilakukan oleh orang yang memiliki power atau kekuasaan dalam pengambilan keputusan,Memaksa ,mengajak agar individu melakukan sesuatu seperti yang diharapkan (bagian dari social planning).

3) Habituasi

Melakukan pembiasaan terhadap aktivitas pemanenan hujan secara kontinyu ,diharapkan akan membuka mind set masyarakat luas ,

\section{4) Group identification}

Masuk dalam komunitas pemanenan air hujan, Menjadi anggota komunitas ,Menciptakan hubungan emosional terhadap seluruh anggota, Mendorong hubungan sosial yang positif., Memberi kesempatan yang sama untuk semua anggota. Berkomunikasi secara terbuka.,Saling menghormati antar anggota.

\section{SIMPULAN}

Sistem Membangun Sense og belonging masyarakat merupakan kajian ecology Citizensip. Ecological Citizenship diistilahkan dengan "memikirkan kewarganegaraan dengan cara-cara agak baru" yang dikaitkan dengan hak dan kewajiban warga negara dalam mencapai lingkungan yang bersih dan sehat. Sense of belonging dimaknai sebagai rasa memiliki terhadap sumber daya alam, dalam kultur jawa disebut dengan istilah "melu handarbeni". Gerakan memanen air hujan merupakan kegiatan untuk menampung air hujan, memanfaatkan secara maksimal,meresapkan kedalam tanah dan mengalirkannya kembali. Kegiatan ini merupakan salah satu alternatif dalam pemanfaatan sumbe daya air yang harus dilakukan masyarakat sebagai cara untuk mewujudkan lingkungan berkelanjutan. 


\section{DAFTAR PUSTAKA}

Aditjondro, G. (2003). Pola-pola gerakan Lingkungan:refleksi Untuk Menyelamatkan Lingkungan dari Ekspansi Modal. Yogyakarta: Pustaka Pelajar.

Anantharaman, M. (2014). Networked Ecological Citizenship,The Middle Classes and The Provisioning Sustinabe waste Management in Bangalore,India. Cleaner Production.

Assshiddiqie, J. (2009). Green Constitution Nuansa Hijau Undang-Undang Dasar Republik Indonesia Tahun 1945. Jakarta: Rajawali Press.

Buttel, F. H. (2010). Social Institution and Enviromental Change. Cheltenham: Edward Elgar Publising .

Curtin, D. (2002). Ecological Citizenship,Handbook of Citizenship Studies. New delhi: SAGE.

D, H. (2009). Environemntal and Ecological Citizenship in Civil Society. International Spectator.

Fernandez Manzanal, R. C. (2007). Evaluation of Environmental Attitudes:Analysis and Result of a scale Applied to University Student. Science education.

FK, K. (2011). Puspa Ragam Konsep dan Isu Kewarganegaraan. Bandung: Widya Aksara Press.

Jagers, e. a. (2014). Ecological Citizenship:A Driver of Pro-Environmental Behaviour?Environmental Politics.

Kent, R. E. (2008). The New Environmental Paradigm. Journal of Environmental Education, 19-28.

Kilbourne, W. E. (2007). The Dominant Social Pradigm,Consumption and Environmental attitudes: Can Macromarketing Education Help? Macromarketing, 106-121.

Maryono, A. (2020, Juni 12). Multi Purposes of Rainwater Harvesting. Yogyakarta, Daerah Istimewa Yogyakarta, Indonesia.

Riley Dunlap\&Catton, W. J. (1979). Environmental Sociology. pp. 243-273.

Saddono, S. S. (2013). Cognive Behaviour Has Replaced The Javanesse Traditional values in Global Era. Asian Journal of Management Sciences and Education, 156-162.

Smith\&Pangsapa, M. J. (2008). Environment and Citizenship Integrating Justice, Responsibility and Civic Engagement. London: Zed Books.

https://www.mongabay.co.id/2018/04/22/menyelamatkan-bumi-yang-satu-lewatperilaku-pro-lingkungan/ 